\title{
PSYCHOLOGICAL AND PEDAGOGICAL PRINCIPLES OF ORGANIZATION OF DISTANCE LEARNING PROCESS IN THE CONTEXT OF COVID-19 PANDEMIC
}

\author{
Mosol N. O. \\ PhD in Psychology, Associate Professor, \\ Associate Professor at the Psychology Department \\ Zaporizhzhia National University \\ Zhukovskoho str., 66, Zaporizhzhia, Ukraine \\ orcid.org/0000-0001-9355-5192 \\ nmosol.spp@gmail.com
}

Fil O. V.

$P h D$ in Pedagogic,

Senior Lecturer at the Department of Pedagogy and Psychology of Educational Activity

Zaporizhzhia National University

Zhukovskoho str., 66, Zaporizhzhia, Ukraine

orcid.org/0000-0002-9458-7994

filshelena@gmail.com

Key words:

distance learning, educational technology, educational innovation, principles of distance learning.
The article deals with psychological and pedagogical principles of application of distance learning technologies in higher education. It is noted that despite the strong interest in distance learning, this method of organizing the educational process has recently become especially important due to the difficult epidemiological conditions. The effectiveness of distance education is based on the use of modern psychological and pedagogical, and informational-communication technologies, and the need and relevance of its development is enshrined in law.

The authors emphasize that the notable features of distance learning as an individualized process of acquiring knowledge, skills, abilities and methods of human cognitive activity are the indirect interaction of participants in the learning process and the formation of a specialized educational environment.

Under normal conditions, distance form of education in Ukraine is voluntary, but in the context of epidemiological emergencies, distance learning is almost the only possible way to ensure the continuity of the educational process, taking into account the individual educational trajectory of the learner.

Rapid implementation and wide distribution of distance learning has revealed the following problematic aspects of its use: lack of proper software and hardware for educators and students, motivation of participants of the educational process, insufficient level of interpersonal communication (and, accordingly, the formation of communicative competence.)

An important condition for the productivity of the organization of the educational process in the realities of distance learning is the observance of the set of principles that constitute a system of requirements for the process of professional training. The defined principles are grouped into three subsystems, namely: the principles that determine the motivation of students (professional orientation and conscious choice); principles that determine the nature of the learning process (flexibility, initiative and activity); principles that characterize the features of interaction between teacher and students (interactivity, mutual learning, self-control, self-regulation and self-correction, the principle of involving the professional "I" of the student). 


\title{
ПСИХОЛОГО-ПЕДАГОГІЧНІ ЗАСАДИ ОРГАНІЗАЦІЇ ДИСТАНЦЙНОГО НАВЧАЛЬНОГО ПРОЦЕСУ В УМОВАХ ПАНДЕМІЇ СОVID-19
}

\author{
Мосол Н. О. \\ кандидат психологічних наук, дочент, \\ доиент кафедри психологіі \\ Запорізький національний університет \\ вул. Жуковського, 66, Запоріжжя, Україна \\ orcid.org/0000-0001-9355-5192 \\ nmosol.spp@gmail.com \\ Філь О. В. \\ кандидат педагогічних наук, \\ старший викладач кафедри педагогіки та психологї̈ освітньої діяльності \\ Запорізький національний університет \\ вул. Жуковського, 66, Запоріжжя, Україна \\ orcid.org/0000-0002-9458-7994 \\ fil8helena@gmail.com
}

\author{
Ключові слова: \\ дистаниійне навчання, \\ освітня технологія, \\ освітня інновація, приничипи \\ дистаниійного навчання.
}

\begin{abstract}
У статті розглядаються психолого-педагогічні засади застосування технологій дистанційного навчання у вищих навчальних закладах. Наголошується, що попри стійкий інтерес до дистанційних форм навчання, особливої значущості такий спосіб організації навчального процесу набув останнім часом у зв'язку зі складними епідеміологічними умовами.

Ефективність дистанційної освіти базується на використанні сучасних психолого-педагогічних та інформаційно-комунікаційних технологій, а необхідність й актуальність іiі розвитку закріплена на законодавчому рівні. Автори підкреслюють, що прикметними рисами дистанційного навчання як індивідуалізованого процесу набуття знань, умінь, навичок і способів пізнавальної діяльності людини є опосередкована взаємодія учасників навчального процесу та сформованість спеціалізованого освітнього середовища.

За звичайних умов дистанційна форма здобуття освіти в Україні $є$ добровільною, але у разі надзвичайних епідеміологічних обставин дистанційне навчання представляється чи не єдино можливим способом забезпечення безперервності освітнього процесу 3 урахуванням індивідуальної освітньої траєкторії здобувача освіти.

Швидке впровадження та широке розповсюдження дистанційного навчання виявило такі проблемні моменти його використання: відсутність належного програмного та технічного забезпечення освітян та здобувачів вищої освіти, мотивація здобувачів освіти, недостатній рівень міжособистісного спілкування і, відповідно, розвитку комунікативної компетентності.

Важливою умовою продуктивності організації освітнього процесу в реаліях дистанційногонавчаннявизначенодотриманнянизкипринципів,якістановлять систему вимог допроцесу фаховоїпідготовки спеціаліста. Визначеніпринципи згруповані в три підсистеми, а саме: принципи, що визначають мотивацію студентів (професійної спрямованості та усвідомленого вибору); принципи, які визначають характер процесу навчання (гнучкості, ініціативності та активності); принципи, що характеризують особливості взаємодії викладача та студентів (інтерактивності, взаємонавчання, самоконтролю, саморегуляції та самокорекції, принцип залучення професійного «Я» студента).
\end{abstract}


Introduction. In today's complex economic and epidemiological conditions, distance learning of future specialists in various fields has become not only the strategic direction of development and reform of the higher education system of Ukraine, but rather a daily necessity.

In general, interest in distance learning has emerged with the development of computer technology and is highly demanded in the higher education market. In Ukraine, the development of distance learning began not so long ago, so its various aspects (theoretical, applied, social) require more study.

The pandemic caused lockdown of educational institutions all over the world and transfer from campus education to distance learning so students could follow social distancing measures. Resent international studies (Seyahi, Ozcan, Sut, Mayer, and Poyraz, 2020) proved that learners were heavily affected by the pandemic. There are socio-psychological effects of both the pandemic and distance learning on students such as feeling of loneliness, decrease in their physical activity, changes in their eating habits, sleep disturbance [1].

The issue of distance learning in higher education has been actively covered in international studies: Anderson, Terry \& Dron, Jon [2]; J. Moore, C. Dickson-Deane, K. Galyen [3]; P. Altbach, L. Reisberg, L. Rumbley [4]; J. Traxler [5]. Various aspects of the application of distance learning technologies in higher education have been covered by research of Ukrainian scientists: O. Voronkin, A. Zabolotsky, V. Logvinenko, B. Shunevich. The psychological aspects of distance learning have been analyzed by M. Zhaldak, Y. Mashbits, M. Smulson, and others.

The main goal of the article is to study the specifics of distance learning in the higher education system in the pandemic and to determine the psychological and pedagogical principles of distance learning technologies in higher education institutions of Ukraine.

Results. In Ukraine, distance education began to develop in the 2000s, which is reflected in legislative documents - the Law of Ukraine "On the National Informatization Program", approved by the Cabinet of Ministers of Ukraine from 23.09.2003 № 1494 "Distance Learning Development Programs for 2004-2006".

In 2013, the Ministry of Education and Science of Ukraine approved the basic principles of organization and implementation of distance learning (Order № 466 "On approval of the Regulation on Distance Learning"), the recognition of distance learning was confirmed in the new version of the Law "On Higher Education", 2019 [6].

Distance learning is defined as an individualized process of acquiring knowledge, skills, abilities, and methods of human cognitive activity, which occurs mainly through the indirect interaction of distant par- ticipants in the learning process in a specialized environment that operates on the basis of modern psychological, pedagogical, information and communication technologies [7].

The analysis of psychological and pedagogical literature gives grounds to consider distance learning as the educational innovation based on modern pedagogical methods, technical means of information transfer as a special type of educational activity, which makes the process flexible, variable, multi-vector allows students to learn on an individual educational trajectory according to personal needs, interests, and abilities.

Distance learning can be carried out at all levels of the educational system, though it is most expedient and acceptable in higher education, and as a method of self-education. The following main elements are used during distance learning: web pages and sites; distance learning courses, e-mail; forums and blogs; chats and messengers; TV and video conferencing; virtual classrooms, etc.

Acting Minister of Education and Science of Ukraine Serhiy Shkarlet emphasizes that "distance education cannot replace real full-time education, but due to the coronavirus pandemic, the whole world is searching for alternative ways in economic and social life. Distance learning is a promising area of education in terms of its digitalization. It is important that the educational process continues, and the high quality and safety of learning should be provided".

Distance learning allows ensuring the individual educational trajectory of the student, as well as the continuity of the educational process in cases of emergencies, which objectively make it impossible to visit educational institutions. In Ukraine, the distance form of education remains exclusively voluntary and, under normal conditions, requires the submission of an appropriate application for enrollment or transfer.

Distance learning technologies are used in most institutions of higher education in Ukraine. Like any other form of education, it has its advantages and disadvantages. We consider it necessary to determine the features of distance learning during the pandemic: The study of the state of distance learning in Ukraine $[8$;9] makes it possible to identify the following problematic issues: lack of material resources of higher education institutions, which lead to restrictions on distance learning during the pandemic, lack of proper software and hardware for educators and graduates, insufficient staffing of distance learning, limited access to the Internet (especially in rural areas), limited access to the computer (usually parents and other family members also work or study from home).

It is important to pay attention to the special requirements of the educational process, to organize the motivation of students. The result of distance learning largely depends on the students' activity, as there is no constant external control. One of the key 
problems of distance learning stays the authentication during knowledge testing.

Also, to the mentioned challenges of distance learning, it is worth considering that communication skills development is an integral part of professional training, and the distance learning environment does not satisfy those requirements sufficiently. Among other psychological problems of distance learning is the issue of maintaining the psycho-emotional state of students in conditions of social isolation. Studies show a persistent negative effect of the pandemic on the mental state of young people.

The effectiveness of the educational process in terms of distance interaction of educational entities depends primarily on the level of student activity, increasing level of their independent work and ensuring constant interaction of students and teachers with appropriate distance learning technologies, as well as creating psychological and pedagogical conditions for cognitive development activity and cognitive independence of students.

Cognitive activity and cognitive independence are the qualities that characterize the ability to learn. We consider activity in the learning process as a general necessary characteristic of the cognitive process. The meaning of the concept of cognitive activity is determined by the desire and interest of the individual to educational activities. By the concept of cognitive independence, we mean the ability of the individual learner to think independently, to have their own point of view, to find their own ways of solving educational problems and so on.

An important condition for the productivity of the organization of the educational process in the realities of distance learning is, in our opinion, compliance with a set of principles that constitute a system of requirements for the process of professional training.

Determining the principles of the educational process in distance learning, we relied on the generally accepted classifications of learning principles of Yu. Babansky [10], I. Lerner [11], M. Skatkin [12] and others and took into account the psychological specifics of distance learning [13].

In a holistic system of principles, we have identified the following subsystems: principles that determine the motivation of students; principles that determine the nature of the learning process; principles that characterize the features of interaction between teacher and students.

Among the principles that determine the motivation of students to distance learning, we have included the principles of professional orientation and conscious choice. The implementation of the principles of this group determines the general orientation of students and their desire to acquire professional knowledge and skills. The professional orientation principle is one of the basic organizational principles of training of future professionals, as it involves the student's awareness of himself as a professional, the formation of personal and professional "I".

The implementation of this principle is based on the principle of conscious choice, which provides an opportunity for students to form their own educational trajectory within the framework of distance learning, taking into account individual educational goals, cognitive interests, time and information resources, the initial level of knowledge and competencies.

The next group of principles determines the nature of the distance learning process. This group includes the principles of flexibility, as well as initiative and activity. The starting point of the principle of flexibility in distance learning is to ensure that both teachers and students can choose the most optimal forms, means, and methods of organizing the educational process to achieve the learning goals through indirect interaction. With the performance of smartphones, smartwatches, and laptops, mobile learning allows students to access learning materials anywhere, often from different devices.

The next principle - initiative and activity - characterizes the professional training and the educational process of mastering professionally important knowledge and skills of future specialists in terms of their position in this process. The bases for the implementation of this principle are the principles of motivation and conscious choice.

The cognitive activity of a student is one of the most important conditions for successful learning because it determines the pace, depth, and strength of the acquisition of new knowledge and the formation of skills and abilities. In the framework of distance learning, the main basis of implementation of the principle of initiative and activity is promoting understanding of the goals and objectives of cognitive activity by students, and the choice of those educational tasks that match their professional interest and level of personal preparedness. The realization of this principle in the activity of educator consists in the use of such forms and methods of organization of educational process, which stimulate the cognitive activity of students, develop their initiative and creative potential, as well as in providing variability of tasks and forms of work that can be chosen by students.

In the situation when distance learning is the main form of education due to the pandemic, it is especially important to ensure productive interaction between teachers and students. The nature of this interaction is determined by the following group of principles: the principle of interactivity, the principle of mutual learning and collective assessment, the principle of self-control, self-regulation, and self-correction, the principle of involving a professional "I".

Students have the opportunity to communicate with educators using modern technologies: through 
distance learning platforms (Moodle, Google Classroom, E-learn), messengers (Viber, Telegram, Facebook). Cisco Webex, Google Meet, Skype, Team Publons, Zoom platforms are used to hold meetings and video-lectures. However, according to feedback and surveys, this does not provide a sufficient level of communication for participants of the educational process. Thus, personal contact of students with each other and with teachers is minimal (or even completely absent). Distance learning does not develop communication skills, does not form teamwork skills.

The principle of interactivity is critical in this group because it reveals the essence of the relationship between teacher and students based on subject-subject interaction as opposed to subject-object, which is the unilateral influence of the teacher (subject) on the individual of a student (object) and does not involve conscious activity of the student in the learning process.

The interactive nature of distance learning involves both the active position of the teacher in the organization of cognitive activity, and student's development, and also conscious initiative, activity, and responsibility of the students for their learning and personal and professional development.

It should be noted, that independent educational activity of students has been in the scope of scientific research in the context of modern educational environment of high school. The independent activity, in turn, affects the students' relationship with teachers by increasing the responsibility for his/her studies, professional and personal development. The active position of future professionals in the educational process of distance learning necessitates allowing them to teach each other under the guidance of a teacher and participate in assessing learning achievements, which is implemented in the principle of mutual learning and collective assessment.

The interaction between students as subjects of the educational process explains the principle of mutual learning. In defining this principle, we have been guided by the researchers' opinion that a person remembers the greatest amount of information gained through the personal involvement and activities or while teaching other people. According to the traditional approach in education, the teacher acts as a tutor, and students usually are just learners. Introduction to the process of traditional learning the elements of mutual learning improve the quality of education by activating the student's awareness in the process of professional training.

It should be noted that such work greatly contributes to the activation of cognitive activity and increases student motivation, which logically leads to strengthening the role of the student in the process of assessing the results of educational and cog- nitive activities and determines compliance with the principle of collective assessment. It is difficult to overestimate the role of assessment in the educational process, as it involves not only quantitative and qualitative assessment of academic achievements, but also acts as controlling, regulatory and stimulating factor; plays the role of positive or negative reinforcement of academic success. Assessment of educational and cognitive activities of students in the process of distance learning is carried out according to two criteria. According to the first - the time of the event - you can select the current and final evaluation. The second method is collective assessment, which includes self-assessment, peer assessment and teacher evaluation. Thus, the assessment (diagnostic, interim, formative, summative) of a student objectively reflects the level of assimilation of theoretical material and the formation of practical skills. Besides, the assessment, which is made collectively taking into account the opinion of the student and classmates, is often beyond doubt and is perceived adequately. Modern educational platforms provide opportunities to use various forms of assessment (teacher, other students, collective assessment.

Self-assessment of educational achievements is based on the following principle - self-control, selfregulation and self-correction. In terms of distance learning, much attention is paid to independent and individual work of students, which involves the development of their ability to independently control, regulate and adjust their learning and personal and professional development. The role of the teacher is to motivate and develop skills of self-control, selfregulation and self-correction. In this case, even without external control by the teacher, the student's cognitive activity will not occur spontaneously, but purposefully, taking into account the individual needs and capabilities.

Recent studies indicate that distance learning stimulates the development of discipline and selforganization, which makes it possible to receive education at a convenient time and place and equal access to education, regardless of place of residence, health or social status (S. Berezhna, I. Prokopenko, 2000).

With the prevalence of distance learning, the absence or significant restriction of direct educational and professional contacts, the adherence to the principle of activation the student 'professional " $I$ " is very important. The starting point of this principle is the understanding that each individual has a creative resource potential for the future profession, but may not be aware of it or do not understand their importance for life. The implementation of this principle depends on the ability of the teacher to identify the resource potential of each student and build further learning 
based on this resource. These can be certain abilities and skills, positive personality traits and qualities, moral characteristics and desires.

During the pandemic when distance learning is often the only way to master the curriculum, students are deprived of the opportunity to interact directly in the educational and professional environment. The primary task of the educators under these conditions is to organize students to explore their own potential as future professionals, understanding the relevance of their own knowledge, skills, qualities, competencies of the chosen profession.

Discussion and conclusions. The COVID-19 pandemic was a challenge that encouraged higher education institutions in Ukraine to implement innovative solutions in a relatively short period and to provide distance learning using various web servers, platforms, resources and social networks.

Distance learning as an educational innovation has its advantages and disadvantages. It is based on modern pedagogical methods, technical means of information transfer as a special type of educational activity, which makes the process flexible, variable, multi-vector, allows students to learn on an individual educational trajectory according to personal needs, interests and abilities.

The effectiveness of the educational process in terms of distance interaction of educational entities depends primarily on the level of student activity, increasing the level of the independent work and ensuring constant interaction of students and teachers with appropriate distance learning technologies, as well as creating psychological and pedagogical conditions for cognitive development activity and cognitive independence of students.

An important condition for the productivity of the educational process in the realities of distance learning is, in our opinion, compliance with several principles, namely: professional orientation and conscious choice, flexibility, initiative and activity, interactivity, mutual learning, collective assessment, activation of professional "I" of a student.

We see prospects for further study of the stated problem in the study of psychological and pedagogical conditions to ensure the effectiveness of distance learning in a pandemic.

\section{Bibliography}

1. Seyahi L., Ozcan S., Sut N., Mayer A., Poyraz B. (2020). Social and Psychiatric Effects of COVID-19 Pandemic and Distance Learning On High School Students: A Cross-Sectional Web-Based Survey Comparing Turkey and Denmark. medRxiv 2020.10.21. doi: https://doi.org/10.1101/2020.10.21.20217406

2. Anderson, Terry \& Dron, Jon (2011). Three Generations of Distance Education Pedagogy. International Review of Research in Open and Distance Learning. 12. 10.19173/irrodl.v12i3.890.

3. Moore, J.L.; Dickson-Deane, C.; Galyen, K (2011). E-Learning, online learning, and distance learning environments: Are they the same? Int. Higher Educ. 2011, 14, 129-135.

4. Trends in Global Higher Education: Tracking an Academic Revolution (2009). UNESCO: Paris, France.

5. Traxler J. (2018). Distance Learning - Predictions and Possibilities. Education Sciences. 8. 35. 10.3390/ educsci8010035.

6. Про вищу освіту : Закон України від 01 липня 2014 р. № 1556-VII / Верховна Рада України. URL: http://zakon.rada.gov.ua/laws/show/1556-18 (дата звернення: 2.11. 2020).

7. Про затвердження Положення про дистанційне навчання. Верховна Рада України. URL: http://zakon.rada.gov.ua/laws/show/z0703-13 (дата звернення: 02.11.2020).

8. Berezhna S., Prokopenko I. Higher Education Institutions in Ukraine during the Coronavirus, or COVID-19, Outbreak: New Challenges vs New Opportunities. Revista Romaneasca pentru Educatie Multidimensionala. 2020, 12 (1.) Sup. 2, 130-135.

9. Сисоєва С.О., Осадча К.П. Стан, технології та перспективи дистанційного навчання у вищій освіті України. Інформаційні технології $і$ засоби навчання. 2019. Т. 70, № 2. С. 271-284.

10. Бабанский Ю.К. Методы обучения в современной общеобразовательной школе. Москва: Просвещение, 1985. 208 с.

11. Лернер И.Я. Дидактические основы методов обучения. Москва: Педагогика, 1981. 186 с.

12. Лернер И.Я., Скаткин М.Н. О методах обучения. Советская педагогика. 1965. № 3. С. 115-127.

13. Дистанційне навчання: психологічні засади : монографія / за ред. М.Л. Смульсон. Кіровоград : Імекс-ЛТД, 2012. 240 с.

\section{References}

1. Seyahi L., Ozcan S., Sut N., Mayer A., Poyraz B. (2020). Social and Psychiatric Effects of COVID-19 Pandemic and Distance Learning On High School Students: A Cross-Sectional Web-Based Survey Comparing Turkey and Denmark. medRxiv 2020.10.21. doi: https://doi.org/10.1101/2020.10.21.20217406

2. Anderson, Terry \& Dron, Jon (2011). Three Generations of Distance Education Pedagogy. International Review of Research in Open and Distance Learning. 12. 10.19173/irrodl.v12i3.890. 
3. Moore, J.L.; Dickson-Deane, C.; Galyen, K (2011). E-Learning, online learning, and distance learning environments: Are they the same? Int. Higher Educ. 2011, 14, 129-135.

4. Trends in Global Higher Education: Tracking an Academic Revolution (2009). UNESCO: Paris, France.

5. Traxler J. (2018). Distance Learning_Predictions and Possibilities. Education Sciences. 8. 35. 10.3390/ educsci8010035.

6. Verkhovna Rada of Ukraine (2014). The Law № 1556-VII "About Higher Education”. http://zakon.rada.gov.ua/laws/show/1556-18. Retrieved: 2020, November , 2. [In Ukrainian].

7. Verkhovna Rada of Ukraine (2015). Pact № 761. "On approval of the Regulations on Distance Learning”. http://zakon.rada.gov.ua/laws/show/z0703-13. Retrieved: 2020, November, 1. [In Ukrainian].

8. Berezhna S., Prokopenko I.(2020). Higher Education Institutions in Ukraine during the Coronavirus, or COVID-19, Outbreak: New Challenges vs New Opportunities. Revista Romaneasca pentru Educatie Multidimensionala. 12 (1.) Sup. 2, 130-135.

9. Sysoieva S, Osadcha K. (2019) Condition, Technologies and Prospects of Distance Learning in the Higher Education of Ukraine. Information Technologies and Learning Tools,№ 48 (70), 271-284. [In Ukrainian]. http://nbuv.gov.ua/UJRN/ITZN_2019_70_2_22

10. Babanskiy Yu. (1985). Metody obuchenija v sovremennoj obshheobrazovatel'noj shkole. (Teaching methods in a modern secondary school) M. : Prosveshhenie. [In Russian].

11. Lerner I. Ya. (1981). Didakticheskie osnovy metodov obucheniya (Didactic foundations of teaching methods). M. : Pedagogy. [In Russian].

12. Lerner I. Ya., Skatkin M.N. (1965). O metodakh obucheniya (On teaching methods). Sovetskaya pedagogika. Volume 3, 115-127. [In Russian].

13. Smulson M., Mashbits Y., Zhaldak M. (2012). Distancijne navchannja: psihologichni zasadi : monografija (Distance learning: psychological principles: monograph). Kirovograd: Imex-LTD. [in Ukrainian]. 